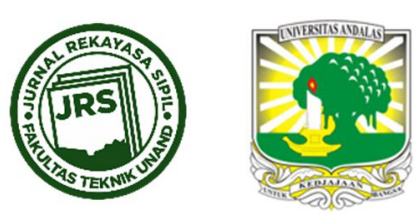

\title{
PENERAPAN STANDAR BANGUNAN TAHAN GEMPA DALAM DETAILED ENGINEERING DESIGN DI SUMATERA BARAT
}

\author{
DES INDRI PRIHANTONY ${ }^{1}$, AFRIZAL ${ }^{2}$, RIKA AMPUH HADIGUNA ${ }^{3}$, TAUFIKA \\ OPHIYANDRI ${ }^{4}$
}

\author{
${ }^{1}$ Prodi Doktor Studi Pembangunan, Universitas Andalas, Padang, Sumatera Barat \\ ${ }^{2}$ Jurusan Sosiologi, Universitas Andalas, Padang, Sumatera Barat \\ ${ }^{3}$ Jurusan Teknik Industri, Universitas Andalas, Padang, Sumatera Barat \\ ${ }^{4}$ Jurusan Teknik Sipil, Universitas, Padang, Sumatera Barat \\ "Corresponding Author : ه prihantony@gmail.com
}

Naskah diterima : 10 Mei 2020. Disetujui: 1 Desember 2020.

\begin{abstract}
ABSTRAK
Penerapan standar bangunan tahan gempa menjadi faktor penting dalam upaya pengurangan risiko bencana di daerah rawan gempa seperti Sumatera Barat. Penerapan tersebut tidak hanya pada saat konstruksi saja tapi juga sudah harus dimulai sejak tahap perencanaan. Penelitian ini bertujuan untuk mengetahui sampai sejauh mana perencanaan teknis bangunan di Sumatera Barat mematuhi standar bangunan tahan gempa yang ditetapkan oleh pemerintah. Metode yang dipergunakan adalah dengan melakukan penghitungan ulang beberapa dokumen perencanaan bangunan publik yang dibuat dalam 10 tahun terakhir dan membandingkannya dengan standar Pedoman Teknis Rumah dan Bangunan Gedung Tahan Gempa dari Kementerian Pekerjaan Umum. Hasil penelitian memperlihatkan bahwa tingkat pemenuhan standar perencanaan bangunan tahan gempa di Sumatera Barat hanya berada di kisaran angka 40,54 sampai 62,16 persen saja. Meskipun secara umum perencanaan-perencanaan tersebut telah memenuhi standar jarak dan diameter sengkang, namun panjang tekukan, panjang penyaluran pembesian, luas tulangan tekan minimum dan luas tulangan tarik minimum tidak terpenuhi. Hal ini sekaligus dapat mengindikasikan bahwa pengalaman gempa besar Padang tahun 2009 yang diikuti oleh kampanye pemerintah tentang bangunan ramah gempa tidak memberikan pengaruh yang signifikan bagi penerapan standar bangunan tahan gempa dalam perencanaan teknis bangunan gedung di Sumatera Barat.
\end{abstract}

Kata kunci : gempa, bangunan tahan gempa, pengurangan risiko bencana, sumatera barat

\section{PENDAHULUAN}

Posisi geologis Indonesia yang berada pada pertemuan beberapa lempeng tektonik yang saling bergerak satu sama lain menyebabkan Indonesia menjadi salah satu wilayah kegempaan yang paling aktif di dunia (Zhang et al., 2015). Di Provinsi Sumatera Barat, data

DOI : https://doi.org/10.25077/jrs.16.3.166-177.2020 
memperlihatkan bahwa sejak tahun 1815 gempa adalah jenis bencana yang merenggut jiwa paling banyak dibanding jenis bencana alam lainnya (Badan Nasional Penanggulangan Bencana, 2017). Dua gempa besar terakhir terjadi pada Maret 2007 (6,5 Skala Richter) dan September 2009 (7,6 Skala Richter). Gempa 2009 menyebabkan 1.195 orang meninggal dunia, 2 orang hilang, 619 orang luka berat dan 1.179 orang luka ringan. Kerusakan infrastruktur meliputi 249.883 rumah, 442 perkantoran, 4.748 fasilitas pendidikan, 153 fasilitas kesehatan, 68 jembatan, 58 pasar dan 2.851 rumah ibadah, dengan perkiraan kerugian mencapai 21,6 Trilyun (Amri et al., 2016). Kajian BNPB juga memperlihatkan bahwa tingkat kerentanan ekonomi Provinsi Sumatera Barat terhadap paparan risiko bencana alam berada pada peringkat 2 secara nasional dengan perkiraan nilai kerugian sebesar Rp. 22,3 Trilyun.

Dengan kondisi ini kesadaran akan risiko bencana gempa menjadi penting bagi industri konstruksi di Sumatera Barat. Idealnya sebuah produk konstruksi harus handal dan dapat memberikan perlindungan maksimal kepada penggunanya pada saat gempa terjadi, sebelum mengalami keruntuhan. Kehandalan itu harus dimulai dari perencanaan teknis yang telah mempertimbangkan aspek gempa dalam perhitungannya. Karena itu penelitian ini bertujuan untuk mengetahui tingkat kepatuhan perencanaan teknis bangunan di Sumatera Barat terhadap standar bangunan tahan gempa yang ditetapkan oleh pemerintah.

Selama ini industri konstruksi telah berkontribusi dalam penanggulangan bencana khususnya pada saat penanganan tanggap darurat serta pada tahap rehabilitasi dan rekonstruksi pascabencana. Namun keterlibatan industri konstruksi tersebut harus diperluas dari semula berupa tindakan reaktif pasca kejadian menuju ke arah tindakan proaktif yang meliputi aktivitas-aktivitas prabencana (Henstra \& McBean, 2005; Witt et al., 2014). Hal ini sejalan dengan perubahan paradigma manajemen penanggulangan bencana yang lebih difokuskan pada kesiapsiagaan, mitigasi bahaya serta pengurangan kerentanan dibanding tindakan-tindakan tanggap darurat dan pemberian bantuan saja (L. Bosher \& Dainty, 2011).

Sekaitan dengan itu Spence dan Kelman (2004) menyatakan bahwa aspek mitigasi bencana harus menjadi salah satu faktor pertimbangan dalam setiap tahapan pembangunan infrastruktur baik tahap perencanaan, disain, konstruksi, operasional, pemeliharaan maupun pengawasan. Karenanya menurut Benson dan Twigg (2007), ahli konstruksi yang memahami aspek kebencanaan harus dilibatkan sejak awal pelaksanaan kegiatan. Keterlibatan sedari awal tersebut akan meningkatkan kepedulian seluruh pelaku dan akan berpengaruh terhadap tindakan pengurangan Risiko bencana dalam proses selanjutnya (L. S. Bosher et al., 2016).

Untuk konteks Sumatera Barat, penelitian Tanjung (2019) yang melakukan investigasi pasca gempa 2007 dan 2009 menyimpulkan bahwa masih banyak kesalahan teknis konstruksi beton bertulang yang ditemukan dalam hubungannya dengan faktor kegempaan. Namun penelitian tersebut tidak mengidentifikasi lebih jauh apakah kesalahan tersebut terjadi pada tahap perencanaan atau pelaksanaan konstruksi.

Dalam Pedoman Teknis Rumah dan Bangunan Gedung Tahan Gempa dari Kementerian Pekerjaan Umum, untuk bangunan gedung bertingkat dengan konstruksi rangka balok dan kolom dari beton bertulang, terdapat 8 (delapan) kriteria yang harus diperhatikan yaitu (Direktorat Jenderal Cipta Karya, 2006):

a. Hubungan plat dengan balok 


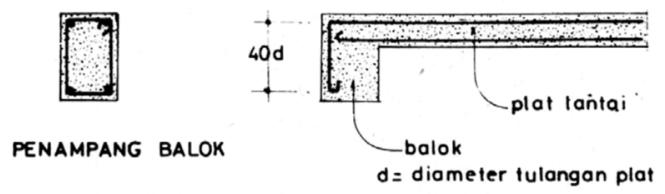

Gambar 1. Hubungan plat lantai dengan balok

b. Hubungan balok anak dan balok induk

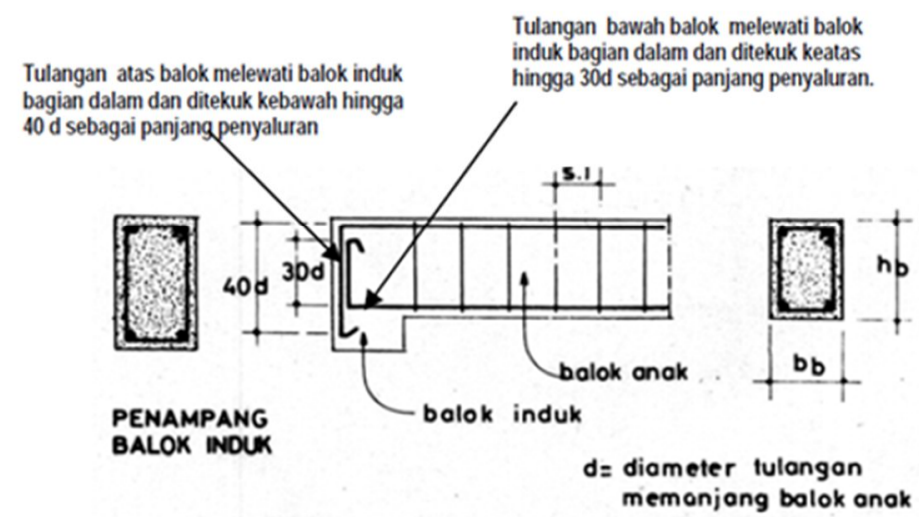

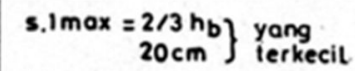

Gambar 2. Hubungan balok anak dan balok induk

c. Hubungan balok atap dengan kolom pinggir
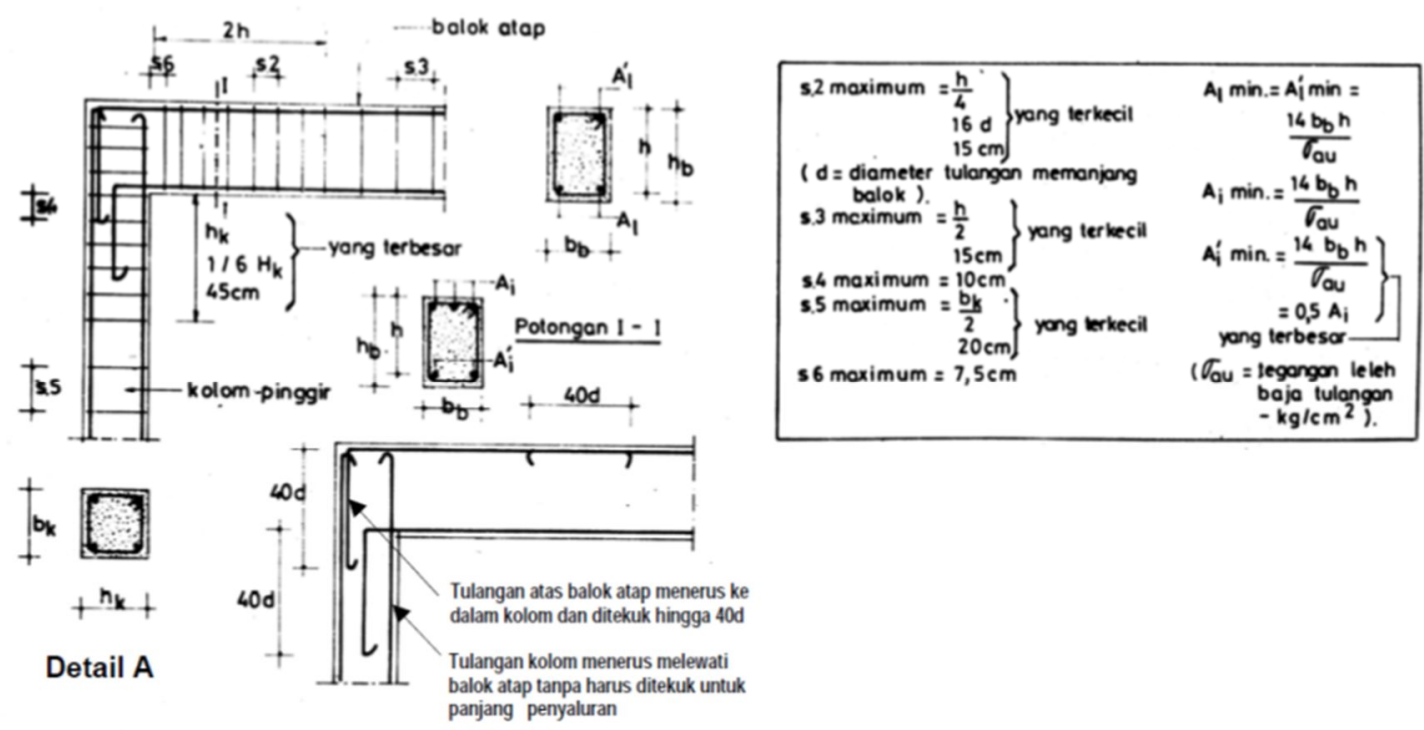

Gambar 3. Hubungan balok atap dengan kolom pinggir

d. Hubungan balok lantai dengan kolom pinggir 


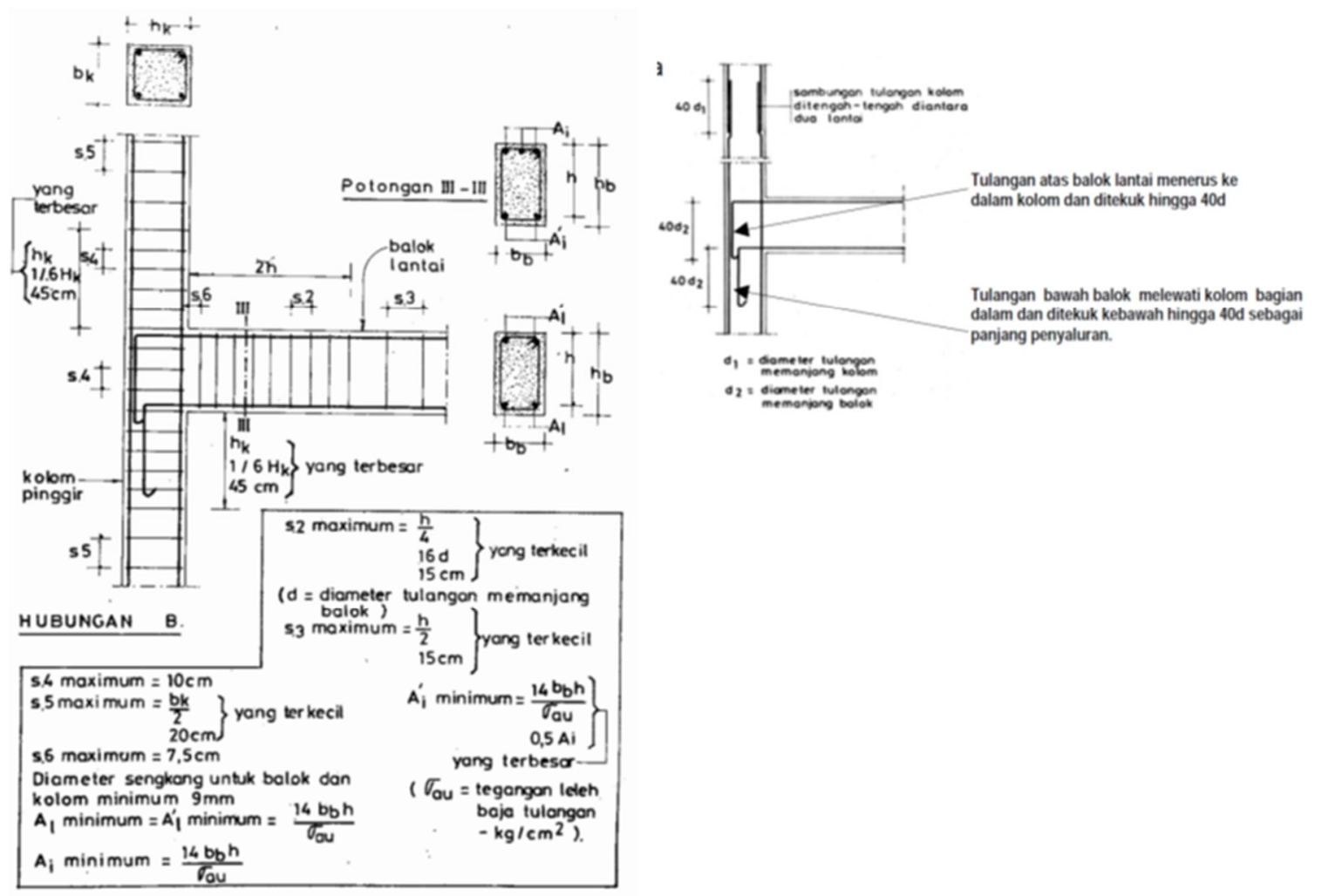

Gambar 4. Hubungan balok lantai dengan kolom pinggir

e. Hubungan balok lantai dengan kolom tengah
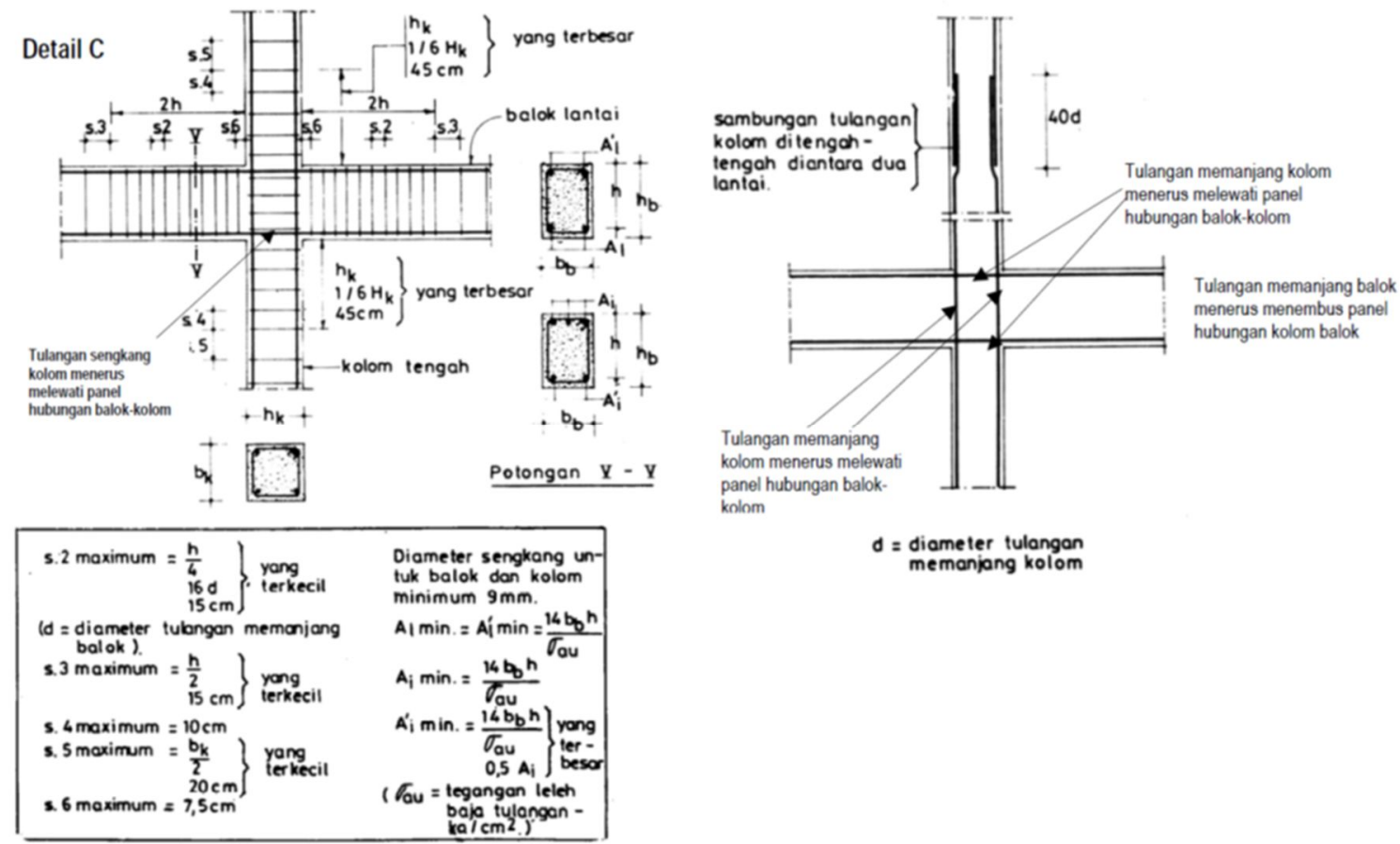

Gambar 5. Hubungan balok lantai dengan kolom tengah 
f. Hubungan pondasi menerus batu kali dengan kolom sudut

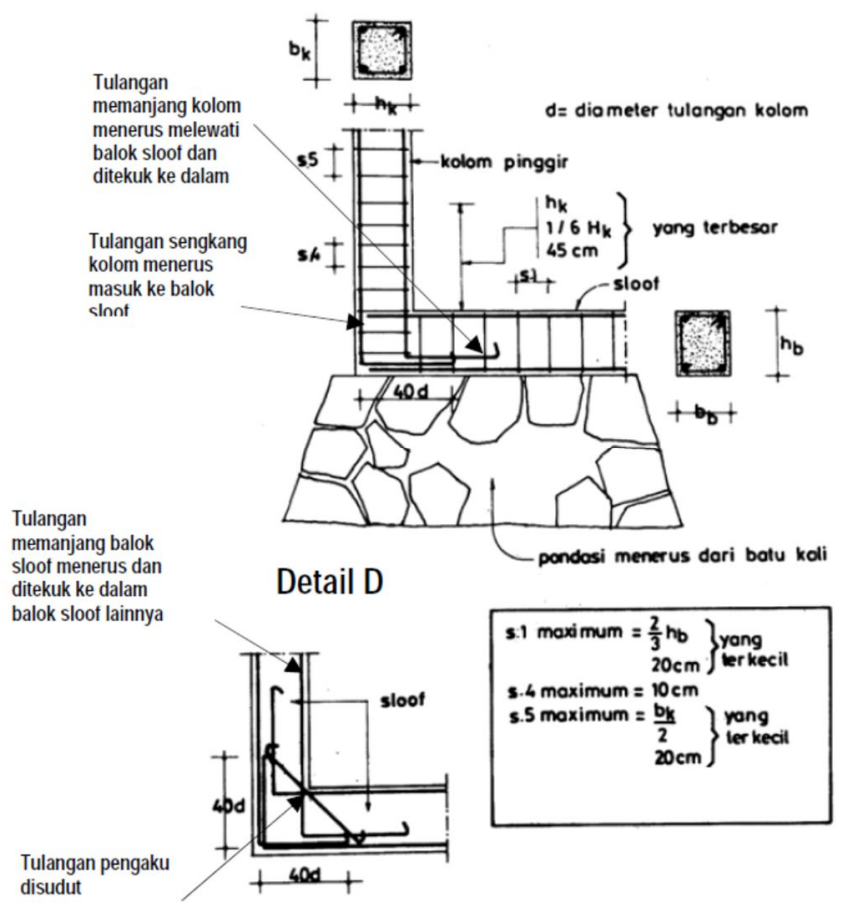

Gambar 6. Hubungan Pondasi Menerus Batu Kali dengan Kolom Sudut

g. Hubungan pondasi menerus batu kali dengan kolom tengah

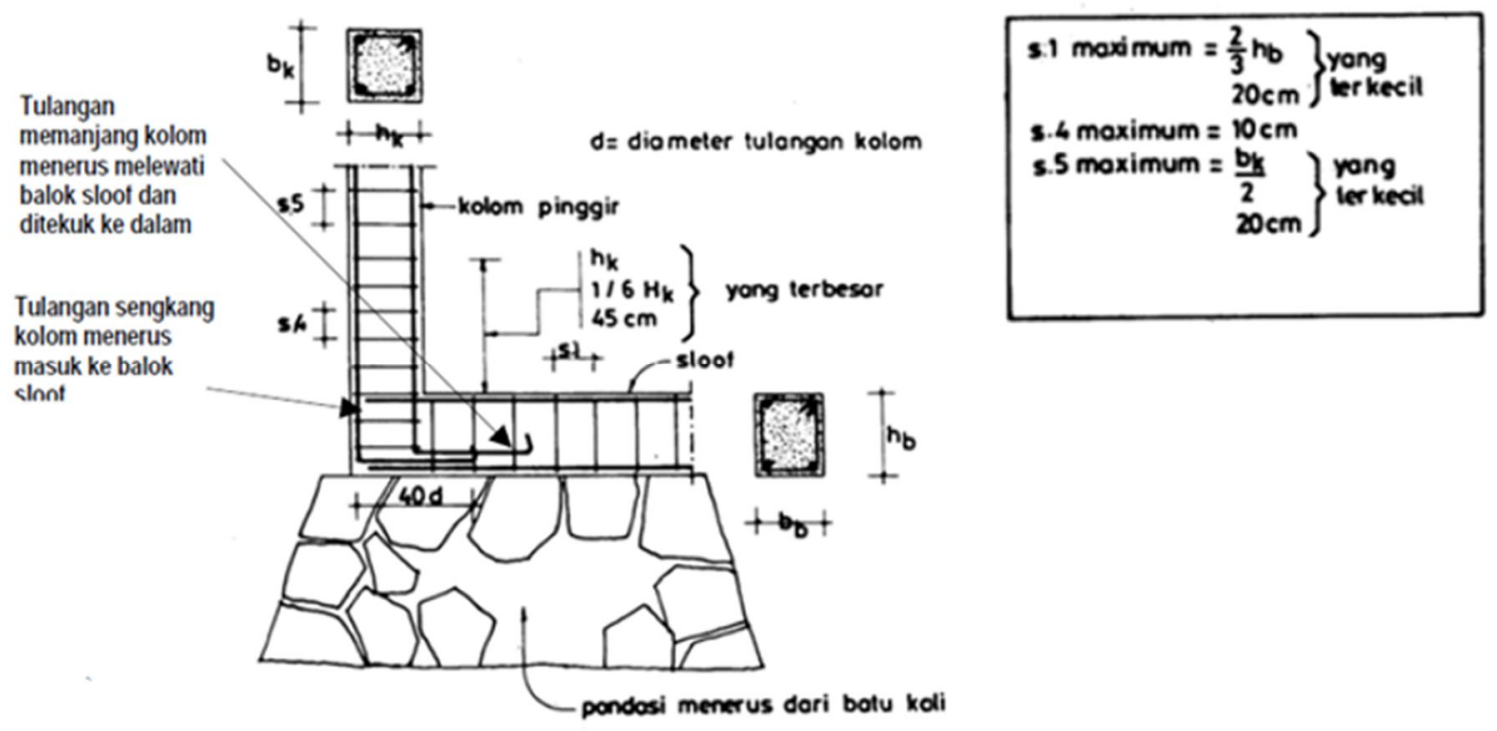

Gambar 7. Hubungan Pondasi Menerus Batu Kali dengan Kolom Tengah

h. Hubungan kolom, balok sloof/balok pengikat dengan pondasi setempat dari beton bertulang 


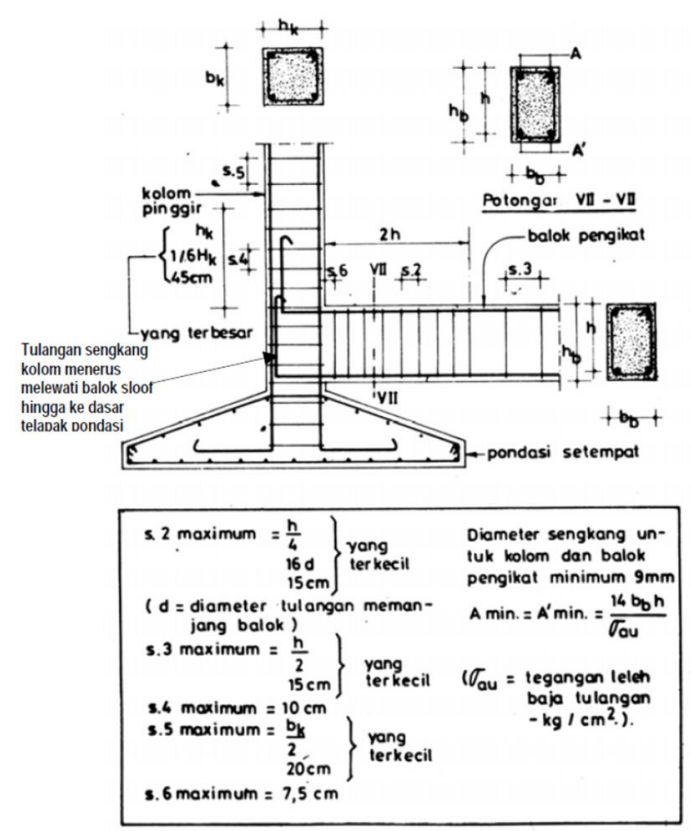

Gambar 8. Hubungan Kolom, Balok Sloof/Balok Pengikat dengan Pondasi Setempat dari Beton Bertulang

\section{METODOLOGI PENELITIAN}

Penelitian ini bersifat kuantitatif yaitu dengan cara melakukan perhitungan ulang dokumen perencanaan teknis bangunan tahun 2010-2018 dan membandingkan hasilnya dengan Pedoman Teknis Rumah dan Bangunan Gedung Tahan Gempa terbitan Direktorat Jenderal Cipta Karya Kementerian Pekerjaan Umum tahun 2006 yang sampai saat ini masih berlaku.

Pedoman ini dipilih karena perhitungannya lebih sederhana dan penghitungan ulang dapat diturunkan dari gambar-gambar disain tanpa memerlukan keseluruhan dokumen perhitungan teknis perencanaan awal.

Adapun kriteria dokumen perencanaan yang dipilih adalah:

1. Dibuat setelah gempa besar Sumatera Barat September 2009, dengan pertimbangan peristiwa gempa besar seharusnya akan meningkatkan kepedulian perencana terhadap faktor gempa.

2. Proyek pemerintah, dengan pertimbangan bahwa proyek milik pemerintah seharusnya telah mematuhi standar yang dibuatnya sendiri.

3. Bangunan beton bertulang 2 lantai atau lebih, dengan pertimbangan bahwa semakin banyak lantai bangunan maka beban gempa akan semakin berpengaruh dan harus menjadi pertimbangan perencana.

4. Struktur berupa infilled frame (kolom dan balok beton bertulang dengan dinding pengisi) untuk keseragaman perbandingan antar bangunan.

5. Penghitungan ulang dilakukan terhadap sejumlah parameter sebagaimana Tabel 1. 
Tabel 1. Parameter untuk setiap kriteria penilaian

\begin{tabular}{lll}
\hline No & \multicolumn{1}{c}{ Kriteria Penilaian } & \multicolumn{1}{c}{ Parameter } \\
\hline 1. & Hubungan plat lantai dengan balok (1) & Panjang Tekukan \\
\hline 2. & Hubungan balok anak dan balok induk (3) & $\begin{array}{l}\text { S1, Panjang Penyaluran } \\
\text { Tulangan Atas, Panjang } \\
\text { Penyaluran Tulangan Bawah }\end{array}$ \\
\hline 3. & Hubungan balok atap dengan kolom pinggir (8) & $\begin{array}{l}\text { S2, S3, S4, S5, S6, Panjang } \\
\text { Penyaluran, Ai Min, A'i Min }\end{array}$ \\
\hline 4. & $\begin{array}{l}\text { Hubungan balok lantai dengan kolom pinggir } \\
\text { (8) }\end{array}$ & $\begin{array}{l}\text { S2, S3, S4, S5, S6, } \varnothing \text { sengkang } \\
\text { balok dan kolom, Ai Min, A'i Min }\end{array}$ \\
\hline 5. & $\begin{array}{l}\text { Hubungan balok lantai dengan kolom tengah } \\
(7)\end{array}$ & $\begin{array}{l}\text { S2, S3, S4, S5, S6, Ai Min, A'i } \\
\text { Min }\end{array}$ \\
\hline 6. & $\begin{array}{l}\text { Hubungan Pondasi Menerus Batu Kali dengan } \\
\text { Kolom Sudut (3) }\end{array}$ & S1, S4, S5 \\
\hline 7. & $\begin{array}{l}\text { Hubungan Pondasi Menerus Batu Kali dengan } \\
\text { Kolom Tengah (3) }\end{array}$ & S1, S4, S5 \\
\hline 8. & $\begin{array}{l}\text { Hubungan Kolom, Balok Sloof/Balok Pengikat } \\
\text { dengan Pondasi Setempat dari Beton Bertulang } \\
(10)\end{array}$ & $\begin{array}{l}\text { S2, S3, S4, S5, S6, Panjang } \\
\text { Penyaluran Sloof, Panjang } \\
\text { balok dan kolom, Ai Min, Ai Min }\end{array}$ \\
\hline
\end{tabular}

\section{HASIL DAN PEMBAHASAN}

Penelitian mengambil 10 (sepuluh) buah sampel dokumen perencanaan sesuai kriteria yang telah ditentukan sebagaimana Tabel. 2. Dari sampel tersebut selanjutnya diambil data-data yang diperlukan untuk perhitungan dari masing-masing gambar rencana yaitu $\mathrm{b}=$ lebar balok/kolom; $\mathrm{h}$ = tinggi balok/kolom; $\mathrm{d}$ = diameter tulangan; $\mathrm{Ai}=$ luas tulangan tarik; $\mathrm{A}^{\prime} \mathrm{i}=$ luas tulangan tekan; sb-k= jarak sengkang balok ke kolom; $\mathrm{pp}=$ panjang penyaluran; $\mathrm{st}=$ jarak sengkang pada tumpuan; sl = jarak sengkang pada lapangan dan $\mathrm{ds}=$ diameter sengkang.

Tabel 2. Informasi DED Proyek Sebagai Sampel Penelitian

\begin{tabular}{llllll}
\hline No & Nama Proyek & Tahun & Jml. Lantai & Perencana & Kualifikasi \\
\hline 1 & DED Gedung Kantor A & 2010 & 4 & CV. S & Kecil \\
\hline 2 & DED Gedung Kantor B & 2010 & 5 & PT. W & Non Kecil \\
\hline 3 & DED Shelter Evakuasi C & 2014 & 4 & PT. K & Non Kecil \\
\hline 4 & DED Gedung Kantor D & 2015 & 4 & PT. R & Non Kecil \\
\hline 5 & DED Gedung Kantor E & 2015 & 3 & PT. A & Non Kecil \\
\hline 6 & DED Gedung Kantor F & 2015 & 4 & PT. M & Non Kecil \\
\hline 7 & DED Asrama G & 2016 & 4 & PT. R & Non Kecil \\
\hline 8 & DED Mesjid H & 2016 & 3 & CV. D & Kecil \\
\hline 9 & DED Gedung Parkir I & 2017 & 4 & CV. N & Kecil \\
\hline 10 & DED Perpustakaan J & 2018 & 3 & CV. C & Kecil \\
\hline
\end{tabular}

Hasil perhitungan sebagaimana terlihat pada Tabel 3 sampai Tabel 9 berikut.

Tabel 3. Hubungan Pelat Lantai dengan Balok

\begin{tabular}{llll}
\hline \multirow{2}{*}{ No } & \multirow{2}{*}{ Gedung } & \multicolumn{2}{c}{ Panjang Tekukan } \\
\cline { 3 - 4 } & & Kebutuhan (cm) & Realisasi (cm) \\
\hline 1. & A & 48 & 0 \\
\hline 2. & B & 40 & 0 \\
\hline 3. & C & 40 & 0 \\
\hline 4. & D & 40 & 0 \\
\hline
\end{tabular}




\begin{tabular}{llll}
\hline \multirow{2}{*}{ No } & \multirow{2}{*}{ Gedung } & \multicolumn{2}{c}{ Panjang Tekukan } \\
\cline { 3 - 4 } & & Kebutuhan $(\mathrm{cm})$ & Realisasi (cm) \\
\hline 5. & E & 40 & 0 \\
\hline 6. & F & 52 & 0 \\
\hline 7. & G & 40 & 0 \\
\hline 8. & H & 40 & 0 \\
\hline 9. & I & 40 & 0 \\
\hline 10. & J & 40 & 0 \\
\hline
\end{tabular}

Dari Tabel 3 terlihat bahwa tidak ada satu sampel pun yang memenuhi kriteria panjang tekukan yang dibutuhkan pada hubungan antara pelat lantai dengan balok.

Tabel 4. Hubungan Balok Anak dengan Balok Induk

\begin{tabular}{|c|c|c|c|c|c|c|c|}
\hline \multirow[t]{2}{*}{ No } & \multirow[t]{2}{*}{ Gedung } & \multicolumn{2}{|c|}{$\begin{array}{l}\text { S.1 Maks } \\
\quad(\mathrm{cm})\end{array}$} & \multicolumn{2}{|c|}{$\begin{array}{c}\text { Panjang } \\
\text { Penyaluran } \\
\text { Tulangan Atas } \\
\text { (cm) }\end{array}$} & \multicolumn{2}{|c|}{$\begin{array}{c}\text { Panjang } \\
\text { Penyaluran } \\
\text { Tulangan } \\
\text { Bawah (cm) } \\
\end{array}$} \\
\hline & & $\mathrm{K}$ & $\mathrm{R}$ & $\mathrm{K}$ & $\mathrm{R}$ & $\mathrm{K}$ & $\mathrm{R}$ \\
\hline 1. & A & 20 & 7,5 & 64 & 0 & 48 & 0 \\
\hline 2. & B & 20 & 20 & 64 & 0 & 48 & 0 \\
\hline 3. & $\mathrm{C}$ & 20 & 10 & 88 & 0 & 66 & 0 \\
\hline 4. & $\mathrm{D}$ & 20 & 10 & 64 & 0 & 48 & 0 \\
\hline 5. & $\mathrm{E}$ & 20 & 8 & 64 & 0 & 48 & 0 \\
\hline 6. & $\mathrm{~F}$ & 20 & 10 & 40 & 0 & 30 & 0 \\
\hline 7. & $\mathrm{G}$ & 20 & 10 & 64 & 0 & 48 & 0 \\
\hline 8. & $\mathrm{H}$ & 20 & 10 & 76 & 65 & 57 & 65 \\
\hline 9. & $\mathrm{I}$ & 20 & 10 & 64 & 0 & 48 & 0 \\
\hline 10. & $\mathrm{~J}$ & 20 & 10 & 64 & 0 & 48 & 0 \\
\hline
\end{tabular}

$\mathrm{K}$ = Kebutuhan; $\mathrm{R}$ = Realisasi

Dari Tabel 4 terlihat bahwa dalam hubungan antara balok anak dengan balok induk, seluruh sampel memenuhi persyaratan standar jarak antar sengkang, namun tidak ada sampel yang memenuhi standar kebutuhan panjang penyaluran tulangan atas. Sedangkan standar kebutuhan panjang penyaluran tulangan bawah hanya dipenuhi oleh 1 dari 10 sampel.

Tabel 5. Hubungan Balok Atap Dengan Kolom Pinggir

\begin{tabular}{|c|c|c|c|c|c|c|c|c|c|c|c|c|c|c|c|c|}
\hline \multirow[t]{2}{*}{ Ged. } & \multicolumn{2}{|c|}{$\begin{array}{l}\text { S.2 } \\
\text { Maks } \\
(\mathrm{cm})\end{array}$} & \multicolumn{2}{|c|}{$\begin{array}{l}\text { S.3 } \\
\text { Maks } \\
(\mathrm{cm}) \\
\end{array}$} & \multicolumn{2}{|c|}{$\begin{array}{l}\text { S.4 } \\
\text { Maks } \\
\text { (cm) } \\
\end{array}$} & \multicolumn{2}{|c|}{$\begin{array}{l}\text { S.5 } \\
\text { Maks } \\
(\mathrm{cm}) \\
\end{array}$} & \multicolumn{2}{|c|}{$\begin{array}{l}\text { S.6 } \\
\text { Maks } \\
(\mathrm{cm}) \\
\end{array}$} & \multicolumn{2}{|c|}{$\begin{array}{l}\text { Panjang } \\
\text { Penyaluran } \\
(\mathrm{cm})\end{array}$} & \multicolumn{2}{|c|}{$\begin{array}{l}\text { Ai Min } \\
(\mathrm{cm} 2)\end{array}$} & \multicolumn{2}{|c|}{$\begin{array}{l}\text { A'i Min } \\
\text { (cm2) }\end{array}$} \\
\hline & $\mathrm{K}$ & $\mathrm{R}$ & $\mathrm{K}$ & $\mathrm{R}$ & $\mathrm{K}$ & $\mathrm{R}$ & $\mathrm{K}$ & $\mathrm{R}$ & $\mathrm{K}$ & $\mathrm{R}$ & $\mathrm{K}$ & $\mathrm{R}$ & $\mathrm{K}$ & $\mathrm{R}$ & $\mathrm{K}$ & $\mathrm{R}$ \\
\hline $\mathrm{A}$ & 10 & 7,5 & 15 & 15 & 10 & 10 & 20 & 20 & 7,5 & 8,0 & 64 & 61 & 3,59 & 2,01 & 3,59 & 2,00 \\
\hline B & 12,5 & 10 & 15 & 20 & 10 & 10 & 20 & 20 & 7,5 & 5,0 & 76 & 25 & 5,39 & 2,83 & 5,38 & 2,80 \\
\hline $\mathrm{C}$ & 8,75 & 10 & 15 & 15 & 10 & 10 & 20 & 15 & 7,5 & 0,0 & 88 & 0 & 3,14 & 3,80 & 3,14 & 3,80 \\
\hline $\mathrm{D}$ & 7,5 & 10 & 15 & 13 & 10 & 10 & 20 & 18 & 7,5 & 2,0 & 52 & 29 & 2,15 & 1,33 & 2,15 & 1,00 \\
\hline $\mathrm{E}$ & 10 & 10 & 15 & 18 & 10 & 10 & 20 & 18 & 7,5 & 0,0 & 64 & 0 & 4,31 & 2,01 & 4,31 & 2,00 \\
\hline $\mathrm{F}$ & 12,5 & 7,5 & 15 & 12,5 & 10 & 7,5 & 20 & 7,5 & 7,5 & 0,0 & 100 & 0 & 5,38 & 4,91 & 5,38 & 5,00 \\
\hline G & 15 & 10 & 15 & 15 & 10 & 10 & 20 & 10 & 7,5 & 7,5 & 76 & 35 & 4,94 & 2,83 & 4,94 & 3,00 \\
\hline $\mathrm{H}$ & 15 & 10 & 15 & 15 & 10 & 10 & 20 & 10 & 7,5 & 5,0 & 76 & 50 & 8,62 & 2,83 & 8,62 & 2,80 \\
\hline I & 8,75 & 10 & 15 & 15 & 10 & 10 & 20 & 15 & 7,5 & 10 & 64 & 50 & 3,14 & 2,10 & 3,14 & 2,00 \\
\hline $\mathrm{J}$ & 15 & 10 & 15 & 15 & 10 & 10 & 15 & 15 & 7,5 & 10 & 64 & 0 & 2,15 & 2,01 & 2,15 & 2,00 \\
\hline
\end{tabular}

Tabel 5 memperlihatkan bahwa dari 5 tipe sengkang yang ada dalam hubungan antara balok atap dengan kolom pinggir, jarak sengkang tipe S.4 dan S.5 dipenuhi oleh semua sampel. Namun pada tipe S.1 dan S.3, 2 dari 10 sampel tidak memenuhi jarak sengkang yang 
dipersyaratkan. Sedangkan 3 dari 10 sampel tidak memenuhi persyaratan jarak sengkang tipe S.6. Selain itu juga terlihat bahwa tidak ada sampel yang memenuhi persyaratan panjang penyaluran tulangan antara balok atap dan kolom pinggir. Sedangkan untuk luas tulangan tekan dan tarik minimum hanya dipenuhi oleh 1 dari 10 sampel.

Tabel 6. Hubungan Balok Lantai dengan Kolom Pinggir

\begin{tabular}{|c|c|c|c|c|c|c|c|c|c|c|c|c|c|c|c|c|}
\hline \multirow[t]{2}{*}{ Ged. } & \multicolumn{2}{|c|}{$\begin{array}{l}\text { S.2 Maks } \\
(\mathrm{cm})\end{array}$} & \multicolumn{2}{|c|}{$\begin{array}{l}\text { S.3 } \\
\text { Maks } \\
\text { (cm) }\end{array}$} & \multicolumn{2}{|c|}{$\begin{array}{l}\text { S.4 } \\
\text { Maks } \\
\text { (cm) }\end{array}$} & \multicolumn{2}{|c|}{$\begin{array}{l}\text { S.5 } \\
\text { Maks } \\
\text { (cm) }\end{array}$} & \multicolumn{2}{|c|}{$\begin{array}{l}\text { S.6 } \\
\text { Maks } \\
\text { (cm) }\end{array}$} & \multicolumn{2}{|c|}{$\begin{array}{l}\varnothing \\
\text { Sengkang } \\
(\mathrm{mm})\end{array}$} & \multicolumn{2}{|c|}{$\begin{array}{l}\mathrm{Ai} \text { Min } \\
(\mathrm{cm} 2)\end{array}$} & $\begin{array}{l}\mathrm{A}^{\prime} \mathbf{i} \\
(\mathrm{cm} 2)\end{array}$ & Min \\
\hline & $\mathrm{K}$ & $\mathrm{R}$ & $\mathrm{K}$ & $\mathrm{R}$ & $\mathrm{K}$ & $\mathrm{R}$ & $\mathrm{K}$ & $\mathrm{R}$ & $\mathrm{K}$ & $\mathrm{R}$ & $\mathrm{K}$ & $\mathrm{R}$ & $\mathrm{K}$ & $\mathrm{R}$ & $\mathrm{K}$ & $\mathrm{R}$ \\
\hline A & 12,5 & 10 & 15 & 20 & 10 & 10 & 20 & 20 & 7,5 & 7,5 & 9 & 13 & 6,28 & 2,83 & 6,28 & 2,83 \\
\hline B & 12,5 & 10 & 15 & 20 & 10 & 10 & 20 & 20 & 7,5 & 5 & 9 & 10 & 5,38 & 2,83 & 5,38 & 2,83 \\
\hline $\mathrm{C}$ & 10 & 10 & 15 & 15 & 10 & 10 & 15 & 15 & 7,5 & 0 & 9 & 10 & 4,31 & 3,80 & 4,31 & 3,80 \\
\hline $\mathrm{D}$ & 15 & 6 & 15 & 18 & 6 & 10 & 20 & 18 & 7,5 & 5 & 9 & 10 & 8,17 & 3,80 & 8,17 & 3,80 \\
\hline $\mathrm{E}$ & 11,25 & 10 & 15 & 18 & 10 & 10 & 20 & 18 & 7,5 & 0 & 9 & 10 & 4,84 & 2,83 & 4,84 & 2,83 \\
\hline $\mathrm{F}$ & 12,5 & 7,5 & 15 & 12,5 & 7,5 & 7,5 & 20 & 7,5 & 7,5 & 0 & 9 & 13 & 5,38 & 4,91 & 5,38 & 4,91 \\
\hline $\mathrm{G}$ & 13,75 & 10 & 15 & 15 & 10 & 10 & 17,5 & 10 & 7,5 & 7,5 & 9 & 8 & 4,94 & 2,83 & 4,94 & 2,83 \\
\hline $\mathrm{H}$ & 15 & 10 & 15 & 15 & 10 & 10 & 20 & 10 & 7,5 & 5 & 9 & 10 & 9,42 & 2,83 & 9,42 & 2,83 \\
\hline I & 8,75 & 10 & 15 & 15 & 10 & 10 & 20 & 15 & 7,5 & 10 & 9 & 10 & 3,14 & 2,01 & 3,14 & 2,01 \\
\hline $\mathrm{J}$ & 12,5 & 10 & 15 & 15 & 10 & 10 & 15 & 15 & 7,5 & 5 & 9 & 10 & 4,49 & 2,83 & 4,49 & 2,83 \\
\hline
\end{tabular}

Dalam hubungan antara balok lantai dan kolom pinggir, Tabel 6 memperlihatkan bahwa jarak maksimum sengkang tipe S.2, S.4 tidak terpenuhi oleh 1 sampel, sedangkan untuk sengkang tipe S.3 tidak terpenuhi oleh 4 dari 10 sampel. Adapun untuk tipe sengkang S.5 semua sampel memenuhi persyaratannya. Terlihat juga bahwa diameter sengkang tidak dipenuhi oleh 1 dari 10 sampel, sedangkan luas penampang minimal tulangan tarik dan tekan tidak dipenuhi oleh semua sampel.

Tabel 7. Hubungan Balok Lantai dengan Kolom Tengah

\begin{tabular}{llllllllllllllll}
\hline Ged. & $\begin{array}{l}\text { S.2 Maks } \\
(\mathrm{cm})\end{array}$ & \multicolumn{2}{l}{$\begin{array}{l}\text { S.3 Maks } \\
(\mathrm{cm})\end{array}$} & \multicolumn{2}{l}{$\begin{array}{l}\text { S.4 Maks } \\
(\mathrm{cm})\end{array}$} & \multicolumn{2}{l}{$\begin{array}{l}\text { S.5 Maks } \\
(\mathrm{cm})\end{array}$} & \multicolumn{2}{l}{$\begin{array}{l}\text { S.6 Maks } \\
(\mathrm{cm})\end{array}$} & $\begin{array}{l}\text { Ai Min } \\
(\mathrm{cm})\end{array}$ & \multicolumn{2}{l}{$\begin{array}{l}\text { A'i Min } \\
(\mathrm{cm})\end{array}$} \\
\hline & $\mathrm{K}$ & $\mathrm{R}$ & $\mathrm{K}$ & $\mathrm{R}$ & $\mathrm{K}$ & $\mathrm{R}$ & $\mathrm{K}$ & $\mathrm{R}$ & $\mathrm{K}$ & $\mathrm{R}$ & $\mathrm{K}$ & $\mathrm{R}$ & $\mathrm{K}$ & $\mathrm{R}$ \\
\hline $\mathrm{A}$ & 12,5 & 10 & 15 & 20 & 10 & 10 & 20 & 20 & 7,5 & 7,5 & 6,28 & 2,83 & 6,28 & 2,83 \\
\hline $\mathrm{B}$ & 12,5 & 10 & 15 & 20 & 10 & 10 & 20 & 20 & 7,5 & 5 & 5,38 & 2,83 & 5,38 & 2,83 \\
\hline $\mathrm{C}$ & 10 & 10 & 15 & 15 & 10 & 10 & 15 & 15 & 7,5 & 0 & 4,31 & 3,80 & 4,31 & 3,80 \\
\hline $\mathrm{D}$ & 15 & 6 & 15 & 18 & 10 & 10 & 20 & 18 & 7,5 & 5 & 8,17 & 3,80 & 8,17 & 3,80 \\
\hline $\mathrm{E}$ & 11,25 & 10 & 15 & 18 & 10 & 10 & 20 & 18 & 7,5 & 0 & 4,85 & 2,83 & 4,85 & 2,83 \\
\hline $\mathrm{F}$ & 12,5 & 7,5 & 15 & 12,5 & 10 & 7,5 & 20 & 7,5 & 7,5 & 0 & 5,38 & 4,91 & 5,38 & 4,91 \\
\hline $\mathrm{G}$ & 13,75 & 10 & 15 & 15 & 10 & 10 & 17,5 & 10 & 7,5 & 7,5 & 4,94 & 2,83 & 4,94 & 2,83 \\
\hline $\mathrm{H}$ & 15 & 10 & 15 & 15 & 10 & 10 & 20 & 10 & 7,5 & 5 & 9,42 & 2,83 & 9,42 & 2,83 \\
\hline $\mathrm{I}$ & 8,75 & 10 & 15 & 15 & 10 & 10 & 20 & 15 & 7,5 & 10 & 3,14 & 2,01 & 3,14 & 2,01 \\
\hline $\mathrm{J}$ & 12,5 & 10 & 15 & 15 & 10 & 10 & 15 & 15 & 7,5 & 5 & 4,49 & 2,83 & 4,49 & 2,83 \\
\hline $\mathrm{K}=$ Kebutuhan; R $=$ Realisasi & & & & & & & & & &
\end{tabular}

Tabel 7 yang memuat hubungan antara balok lantai dengan kolom tengah memperlihatkan bahwa persyaratan jarak maksimum sengkang tipe S.2, S.4 dan S.5 dipenuhi oleh semua sampel. Sedangkan untuk sengkang tipe S.3 terdapat 4 sampel yang tidak memenuhi persyaratan jarak maksimal, sementara untuk tipe S.6 hanya 1 sampel yang tidak memenuhi persyaratan. Adapun untuk luas penampang tulangan tarik dan tekan minimum juga tidak ada sampel yang memenuhinya.

Dari 10 sampel, 3 diantaranya memiliki jenis pondasi batu kali. Hubungan antara pondasi batu kali dengan kolom diperlihatkan dalam Tabel 8. 
Tabel 8. Hubungan Pondasi Batu Kali dengan Kolom

\begin{tabular}{|c|c|c|c|c|c|c|c|c|c|c|c|c|}
\hline \multirow{3}{*}{ Ged. } & \multicolumn{6}{|c|}{ Hub. Pondasi Batu Kali dg Kolom Sudut } & \multicolumn{6}{|c|}{ Hub. Pondasi Batu Kali dg Kolom Tengah } \\
\hline & \multicolumn{2}{|c|}{ S.1 Maks } & \multicolumn{2}{|c|}{ S.4 Maks } & \multicolumn{2}{|c|}{ S.5 Maks } & \multicolumn{6}{|c|}{$\begin{array}{lll}\text { S.1 Maks } & \text { S.4 Maks } & \text { S.5 Maks } \\
\end{array}$} \\
\hline & $\mathbf{K}$ & $\mathbf{R}$ & $\mathbf{K}$ & $\mathbf{R}$ & $\mathbf{K}$ & $\mathbf{R}$ & K & $\mathbf{R}$ & $\mathbf{K}$ & $\mathbf{R}$ & $\mathbf{K}$ & $\mathbf{R}$ \\
\hline A & 13,33 & 20 & 10 & 0 & 0 & 0 & 13,33 & 20 & 10 & 0 & 0 & 0 \\
\hline $\mathrm{C}$ & 20 & 0 & 10 & 0 & 20 & 0 & 20 & 0 & 10 & 0 & 20 & 0 \\
\hline $\mathrm{J}$ & 13,33 & 20 & 10 & 0 & 0 & 0 & 13,33 & 20 & 10 & 0 & 0 & 0 \\
\hline
\end{tabular}

Dari tabel 8 terlihat bahwa dari tiga tipe sengkang, hanya pada tipe S.1 yang dipenuhi persayaratannya oleh 2 dari 3 sampel. Sedangkan untuk tipe sengkang S.4 dan S.5 seluruh sampel tidak memenuhi persyaratan.

Tabel 9. Hub. Kolom, Balok Sloof/ Balok Pengikat dengan Pondasi Setempat dari Beton Bertulang

\begin{tabular}{|c|c|c|c|c|c|c|c|c|c|c|c|c|c|c|c|c|c|c|c|c|}
\hline & \multirow{2}{*}{\multicolumn{2}{|c|}{$\begin{array}{l}\text { S.2 Maks } \\
(\mathrm{cm})\end{array}$}} & \multirow{2}{*}{\multicolumn{2}{|c|}{$\begin{array}{l}\text { S.3 } \\
\text { Maks } \\
\text { (cm) }\end{array}$}} & \multirow{2}{*}{\multicolumn{2}{|c|}{$\begin{array}{l}\text { S.4 } \\
\text { Maks } \\
\text { (cm) }\end{array}$}} & \multirow{2}{*}{\multicolumn{2}{|c|}{$\begin{array}{l}\text { S.5 Maks } \\
(\mathrm{cm})\end{array}$}} & \multirow{2}{*}{\multicolumn{2}{|c|}{$\begin{array}{l}\text { S.6 } \\
\text { Maks } \\
\text { (cm) }\end{array}$}} & \multicolumn{4}{|c|}{$\begin{array}{l}\text { Panjang } \\
\text { Penyaluran }(\mathrm{cm})\end{array}$} & \multirow{2}{*}{\multicolumn{2}{|c|}{$\begin{array}{l}\varnothing \\
\text { Seng- } \\
\text { kang } \\
(\mathrm{mm})\end{array}$}} & \multirow{2}{*}{\multicolumn{2}{|c|}{$\begin{array}{l}\text { Ai Min } \\
(\mathrm{cm} 2)\end{array}$}} & \multirow{2}{*}{\multicolumn{2}{|c|}{$\begin{array}{l}\text { A'i Min } \\
(\mathrm{cm} 2)\end{array}$}} \\
\hline & & & & & & & & & & & \multicolumn{2}{|c|}{ Sloof } & \multicolumn{2}{|c|}{ Kolom } & & & & & & \\
\hline & $\mathrm{K}$ & $\mathrm{R}$ & $\mathrm{K}$ & $\mathrm{R}$ & $\mathrm{K}$ & $\mathrm{R}$ & $\mathrm{K}$ & $\mathrm{R}$ & $\mathrm{K}$ & $\mathrm{R}$ & $\mathrm{K}$ & $\mathrm{R}$ & $\mathrm{K}$ & $\mathrm{R}$ & $\mathrm{K}$ & $\mathrm{R}$ & $\mathrm{K}$ & $\mathrm{R}$ & $\mathrm{K}$ & $\mathrm{R}$ \\
\hline $\mathrm{A}$ & 15 & 10 & 15 & 20 & 10 & 10 & 20 & 20 & 7,5 & 7,5 & 76 & 46 & 64 & 31 & 9 & 13 & 8,79 & 2,83 & 8,79 & 2,83 \\
\hline B & 10 & 15 & 15 & 15 & 10 & 10 & 20 & 20 & 7,5 & 0 & 64 & 0 & 76 & 25 & 9 & 10 & 4,31 & 2,01 & 4,31 & 2,01 \\
\hline $\mathrm{C}$ & 10 & 10 & 15 & 15 & 10 & 10 & 15 & 15 & 7,5 & 0 & 88 & 0 & 88 & 35 & 9 & 10 & 4,31 & 3,80 & 4,31 & 3,80 \\
\hline $\mathrm{D}$ & 15 & 9,5 & 15 & 20 & 10 & 10 & 20 & 18 & 7,5 & 5 & 88 & 60 & 88 & 31 & 9 & 10 & 10,05 & 3,80 & 10,1 & 3,80 \\
\hline $\mathrm{E}$ & 11,3 & 10 & 15 & 18 & 10 & 10 & 20 & 18 & 7,5 & 0 & 76 & 0 & 76 & 15 & 9 & 10 & 4,85 & 2,83 & 4,85 & 2,83 \\
\hline $\mathrm{F}$ & 12,5 & 7,5 & 15 & 12,5 & 10 & 7,5 & 20 & 7,5 & 7,5 & 0 & 100 & 0 & 100 & 12,6 & 9 & 13 & 5,38 & 4,91 & 5,38 & 4,91 \\
\hline $\mathrm{G}$ & 11,3 & 10 & 15 & 15 & 10 & 10 & 17,5 & 10 & 7,5 & 7,5 & 64 & 35 & 76 & 40,9 & 9 & 8 & 4,04 & 2,01 & 4,04 & 2,01 \\
\hline $\mathrm{H}$ & 12,5 & 10 & 15 & 15 & 10 & 10 & 20 & 10 & 7,5 & 5 & 76 & 0 & 76 & 180 & 9 & 8 & 4,49 & 2,83 & 4,49 & 2,83 \\
\hline $\mathrm{I}$ & 12,5 & 10 & 15 & 10 & 10 & 10 & 20 & 15 & 7,5 & 10 & 76 & 0 & 88 & 15 & 9 & 10 & 5,38 & 2,83 & 5,38 & 2,83 \\
\hline $\mathrm{J}$ & 10 & 10 & 15 & 15 & 10 & 10 & 15 & 15 & 7,5 & 5 & 64 & 0 & 64 & 20 & 9 & 10 & 2,87 & 2,01 & 2,87 & 2,01 \\
\hline
\end{tabular}

Untuk pondasi setempat dari beton bertulang, hubungannya dengan kolom dan sloof diperlihatkan dalam Tabel 9. Hasil perhitungan menunjukkan bahwa jarak maksimum sengkang tipe S.4 dan S.5 dipenuhi oleh semua sampel. Namun demikian pada sengkang tipe S.2 dan S.6 tidak dipenuhi oleh 1 sampel untuk tiap tipe, sedangkan untuk sengkang tipe S.3 terdapat 3 sampel yang tidak memenuhi persyaratan jarak maksimum. Adapun untuk diameter sengkang balok dan kolom, 2 sampel tidak memenuhi persyaratan. Demikian juga untuk luas penampang minimum tulangan tarik dan tekan, tidak ada satu pun sampel yang memenuhinya.

Dari hasil perhitungan diatas, Tabel 10 memuat status pemenuhan kriteria umum oleh keseluruhan sampel. Terlihat bahwa hanya jarak dan diameter sengkang yang terpenuhi, sedangkan panjang tekukan dan penyaluran pembesian serta luas tulangan minimum tarik dan tekan tidak terpenuhi.

Tabel 10. Status Pemenuhan Kriteria Umum oleh Seluruh Sampel

\begin{tabular}{lll}
\hline No & Kriteria Umum & Status \\
\hline 1 & Panjang tekukan pembesian & Tidak memenuhi \\
\hline 2 & Panjang penyaluran pembesian & Tidak memenuhi \\
\hline 3 & Jarak sengkang & Umumnya memenuhi \\
\hline 4 & Diameter sengkang & Umumnya memenuhi \\
\hline 5 & Luas tulangan tekan minimum & Tidak memenuhi \\
\hline 6 & Luas tulangan tarik minimum & Tidak memenuhi \\
\hline
\end{tabular}


Tabel 11 memuat rekapitulasi pemenuhan standar oleh sampel untuk 43 item kriteria penilaian. Dari tabel terlihat bahwa pemenuhan standar tertinggi adalah 62,16 persen (sampel H), sedangkan terendah adalah 40,54 persen (sampel E). Dari tabel juga diketahui bahwa hanya 4 dari 10 sampel yang memenuhi diatas 50 persen persyaratan bangunan tahan gempa.

Tabel 11. Pemenuhan Standar oleh Sampel (43 item)

\begin{tabular}{lllll}
\hline \multirow{2}{*}{ No } & \multirow{2}{*}{ Gedung } & \multicolumn{2}{l}{ Pemenuhan Standar (item) } & $\begin{array}{l}\text { Persentase } \\
\text { terpenuhi }\end{array}$ \\
\cline { 3 - 5 } & & Ya & Tidak & 44,19 \\
\hline 1. & DED Gedung Kantor A & 19 & 24 & 48,65 \\
\hline 2. & DED Gedung Kantor B & 18 & 19 & 46,51 \\
\hline 3. & DED Shelter Evakuasi C & 20 & 23 & 48,65 \\
\hline 4. & DED Gedung Kantor D & 18 & 19 & 40,54 \\
\hline 5. & DED Gedung Kantor E & 15 & 22 & 51,35 \\
\hline 6. & DED Gedung Kantor F & 19 & 18 & 56,75 \\
\hline 7. & DED Asrama G & 21 & 16 & 62,16 \\
\hline 8. & DED Mesjid H & 23 & 14 & 43,24 \\
\hline 9. & DED Gedung Parkir I & 16 & 21 & 53,49 \\
\hline 10. & DED Perpustakaan J & 23 & 20 & \\
\hline
\end{tabular}

Jika kita menghubungkan pemenuhan standar dengan tahun pembuatan dokumen perencanaan, maka grafik masing-masing sampel akan terlihat seperti Gambar 9.

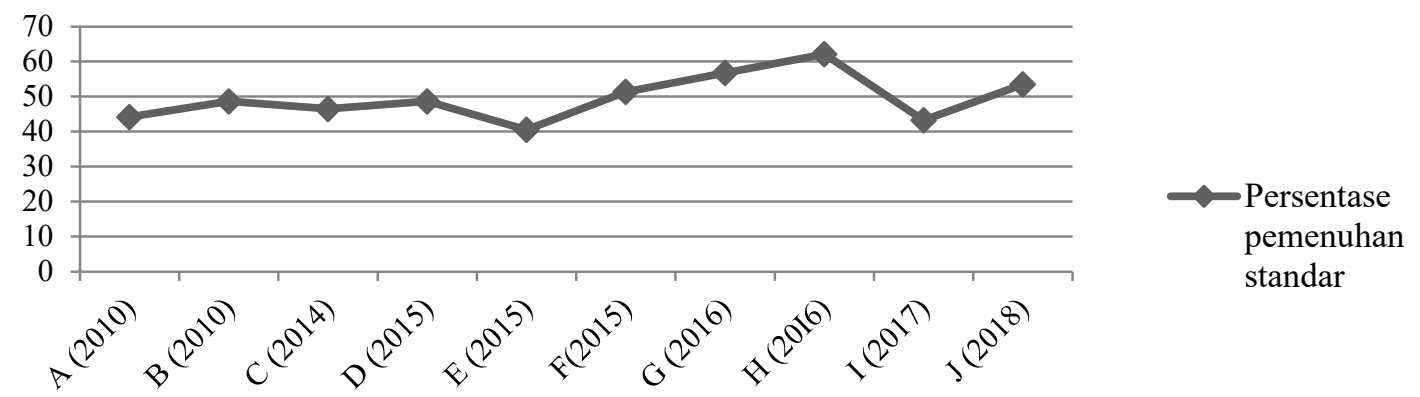

Gambar 9. Grafik hubungan tahun perencanaan dan pemenuhan standar oleh sampel

Dari Gambar 9 terlihat bahwa grafik terlihat fluktuatif dan cenderung datar. Hal ini mengindikasikan bahwa praktik penerapan standar bangunan tahan gempa oleh perencana di Sumatera Barat tidak menunjukkan peningkatan yang berarti dalam 10 tahun terakhir. Dengan demikian dapat diasumsikan bahwa pengalaman gempa besar Padang tahun 2009 dan kampanye pendidikan publik "Bangunan Ramah Gempa" oleh pemerintah pasca gempa tersebut, baik melalui media cetak, elektronik, media luar ruang dan pelatihan, tidak cukup membuat para perencana bangunan di Sumatera Barat menjadi lebih peduli terhadap aspek kegempaan.

Jika dihubungkan dengan bentuk badan usaha yang dimiliki oleh sampel, terlihat bahwa praktik kurangnya penerapan aspek kegempaan ini ditemukan pada seluruh sampel. Hal ini juga mengindikasikan bahwa perencana yang memiliki badan usaha dengan kualifikasi yang lebih tinggi tidak otomatis memiliki standar yang lebih tinggi dalam penerapan standar bangunan tahan gempa di Sumatera Barat. 


\section{KESIMPULAN}

Dari perhitungan ulang dokumen perencanaan yang dipilih sebagai sampel terlihat bahwa tingkat penerapan standar bangunan tahan gempa pada perencanaan teknis di Sumatera Barat masih relatif rendah, yaitu antara 40,54 dan 62,16 persen saja. Penelitian juga memperlihatkan tidak adanya peningkatan yang berarti dalam kurun waktu 2010-2018. Hasil ini ditemukan pada seluruh kualifikasi perencana, baik kecil maupun non kecil.

Kondisi ini menunjukkan bahwa penerapan standar bangunan tahan gempa dalam produk perencanaan bangunan tidak bergantung kepada adanya standar dan pengetahuan teknis perencana semata. Aspek kepedulian perencana terhadap kegempaan harus tetap didorong secara berkelanjutan untuk membuatnya terwujud.

Karena pendekatan penelitian ini terbatas hanya dilakukan terhadap gambar disain, maka sebaiknya juga perlu dilakukan telaahan terhadap produk perhitungan disain sampel secara keseluruhan. Hal ini karena terdapat kemungkinan bahwa yang terjadi adalah kesalahan pada waktu detailing gambar, meskipun perhitungan teknisnya sudah mengacu kepada tata cara perencanaan ketahanan gempa sebagaimana diatur dalam SNI 03-1726-2002 atau 1726-2012, namun terjadi. Tidak terlepas juga adanya kemungkinan ketidaksinkronan antar peraturan, dalam hal ini antara SNI dan pedoman teknis yang menjadi acuan penelitian ini.

\section{DAFTAR PUSTAKA}

Amri, M. R., Yulianti, G., Yunus, R., Wiguna, S., Adi, A. W., Ichwana, A. N., Randongkir, R. E., \& Septian, R. T. (2016). Risiko Bencana Indonesia. Badan Nasional Penanggulangan Bencana. http://inarisk.bnpb.go.id/pdf/Buku RBI_Final_low.pdf

Badan Nasional Penanggulangan Bencana. (2017). Data dan Informasi Bencana Indonesia. http://dibi.bnpb.go.id/data-bencana/.

Benson, C., \& Twigg, J. (2007). Tools for Mainstreaming Disaster Risk Reduction: Organisations Tools for Mainstreaming Disaster Risk: Disaster Risk. Int. Fed. Red Cross Red Crescent Soc./ProVention Consort, 1-184.

Bosher, L., \& Dainty, A. (2011). Disaster risk reduction and 'built-in'resilience: towards overarching principles for construction practice. Disasters, 35(1), 1-18. https://doi.org/http://dx.doi.org/10.1111/j.1467-7717.2010.01189.x

Bosher, L. S., Von Meding, J., Johnson, C., Arefian, F. F., Chmutina, K., \& Chang-Richards, Y. (2016). Disasters and the built environment. Research roadmap. https://s3-eu-west1.amazonaws.com/pstorage-loughborough53465/17084240/CIBW120RoadmapPublication.pdf

Direktorat Jenderal Cipta Karya. (2006). Pedoman Teknis Rumah dan Bangunan Gedung Tahan Gempa dilengkapi dengan Metode dan Cara Perbaikan Kerusakan. Kementerian Pekerjaan Umum.

http://ciptakarya.pu.go.id/dok/hukum/pedoman/pedoman_teknis_bangunan_tahan_gempa. pdf

Henstra, D., \& McBean, G. (2005). Canadian disaster management policy: Moving toward a paradigm shift? Canadian Public Policy/Analyse de Politiques, 31(3), 303-318.

Spence, R., \& Kelman, I. (2004). Editorial. Building Research \& Information, 32(5), 364-367. https://doi.org/10.1080/0961321042000244129

Tanjung, J. (2019). Investigasi Pasca Bencana Gempa Bumi: Identifikasi Kesalahan Konstruksi Beton Bertulang. Fakultas Teknik Unand.

Witt, E., Sharma, K., \& Lill, I. (2014). Mapping construction industry roles to the disaster management cycle. Procedia Economics and Finance, 18, 103-110.

Zhang, L., Liao, W., Li, J., \& Wang, Q. (2015). Estimation of the 2010 Mentawai tsunami earthquake rupture process from joint inversion of teleseismic and strong ground motion data. Geodesy and Geodynamics, 6(3), 180-186. 